\title{
Ammatillinen harjoittelu asiantuntijuuden kehittäjänä
}

\author{
Marja-Liisa Vesterinen
}

\author{
Filosofian tohtori, kauppatieteiden lisensiaatti Marja- \\ Liisa Vesterisen tuore aikuiskasvatuksen väitöskirja (JY) \\ tarkastelee, miten ammattikorkeakouluopiskelijoiden \\ ammatillisen osaaminen kehittyy harjoittelun tuloksena.
}

$\mathrm{T}$ utkimusaineisto syntyi Etelä.-Karjalan ammattikorkeakoulun ESR-rahoitteisessa ammatillisen harjoittelun ehittämisprojektissa, jossa harjoittelulle asetettiin selkeitä oppimistavoitteita ja jossa työssä oppiminen pedagogisoitiin uudella tavalla. Harjoittelua integroitiin myös osaksi opetussuunnitelmaa. Tutkimuksessa selvitettiin myös, miten amk-opettajien ja työpaikan ohjaajien osaaminen ja asenne työpaikalla tapahtuvaan oppimiseen muuttui prosessin tuloksena.

Tutkimus on osa ammattikorkeakoulun kehittämistyötä, mutta se sivuaa myös ajankohtaista koulutuspolitiikkaa, työelämän kehittämistä ja uuden tiedon tarvetta siitä, miten yhä tärkeämmäksi oppimisen muodoksi osoittautunut työssä oppiminen voidaan liittää osaksi ammattikorkeakouluopintoja ja integroida opetussuunnitelmaan. Harjoittelujakso lienee myös ensimmäinen omakohtainen ja konkreettinen tilanne, jossa opiskelijatkin oivaltavat, mitä on elinikäinen oppiminen.

1990-luvun alussa tehtiin koulutuspoliittisia ratkaisuja siitä, että Suomen korkeakoulujärjestelmä on duaalinen, kaksijakoinen. Tuolloin syntyivät ammattikorkeakoulut. Yliopistot ovat tiedekorkeakouluja, ammattikorkeakoulut puolestaan suuntautuvat ammatillisten asiantuntijoiden kouluttamiseen ja työelämän kehittämiseen. Ammattikorkeakoulut ovat suomalaisen korkeakoulujärjestelmän duaalimallissa se osa , jonkatehtävänäonyhdistääteoriajakäytäntöammatilliseksiasiantuntijundeksi, todelliseksi ammatilliseksi osaamisek- si. Arkitodellisuudessa on oppimisessa valitettavasti usein läsnä vain jompikumpi, teoria tai käytäntö, vaikka niiden pitäisi kulkea toisiinsa nojaten ja toisiaan täydentäen sekä opetussuunnitelmissa että käytännön oppimisprosessissa. Opetussuunnitelmat rakentuvat yhä siten, että ammattikorkeakoulun seinien sisäpuolella pyritään saavuttamaan kaikki ennalta suunnitellut oppimistavoitteet. Käytännön harjoittelu suoritetaan opetussuunnitelmasta irrallisena osana, jolla ei ole selkeitä oppimis- tai laatutavoitteita tai riittävää ja osaavaa ohjausta ja jota ei yhdistä koulussa opiskeltaviin aiheisiin sen enempää opiskelija, opettaja kuin kukaan muukaan.

\section{Muistetaan myös ammattikorkea- koulun perustehtävä}

Huolimatta viimeaikaisesta keskustelusta, jossa on väännetty kättä ammattikorkeakoulujen jatkotutkinnoista, tutkimustyöstä ja mm. amk-professorien tarpeellisuudesta tai ammattikorkeakoulujen kuvitellusta pyrkimyksestä tulla yliopistojen kaltaisiksi, on mielessä pidettävä se, että ammattikorkeakoulujen perustehtävänä on edelleen opiskelijoiden kouluttaminen asiantuntija- ja kehittämistehtäviin. Se on ammattikorkeakoulujen olemassaolon peruste. Siksi kehittämistyön tulee kohdistua yhä edelleen myös perustehtävässä onnistumiseen.

Tarve ammatillisten asiantuntijoiden koulutukseen tulee työelämästä. Yhteiskunta, työ ja 
työpaikkojen toimintaympäristöt muuttuvat ja edellyttävät entistä parempaa osaamista yritysten kilpailukyvyn säilyttämiseksi. Amk-tutkinnon suorittaneilta odotetaan korkeatasoista ja monialaista tietoa, mutta myös kykyä tarttua käytännön työhön ilman, että heitä täytyy opettaa työpaikalla pitkään ennen kuin käytännön työ sujuu. Osaamisen on oltava sekä horisontaalisesti laajaa että vertikaalisesti syvää ja moniportaista. Yksilöiden osaamisen tulee yltää suoritustehtävistä esimiestaitoihin asti. Ammattikorkeakoulusta valmistuvien odotetaan kykenevän osallistumaan työn ja työyhteisöjen kehittämiseen. Siihen tarvitaan kokemusta, työn ja alan sekä yhteisön kulttuurin sisäistämistä eli teoriatiedon rinnalle tarvitaan käytännön työssä ja työstä oppimista.

Ammattikorkeakoulut kilpailevat yliopistojen kanssa siitä, kumpi tarjoaa opiskelijoille paremmat lähtökohdat työelämää varten. Ammattikorkeakoulujen ehdoton vahvuus on koulutuksen ammatillisuus. Omaleimaista profiiliaan ammattikorkeakoulut rakentavat $\mathrm{mm}$. ajankohtaisten, työelämän nykyisiin ja tuleviin tarpeisiin vastaavien koulutusohjelmien avulla. Ammatillisen harjoittelun pakollisuus ja sen kehittäminen on yksi merkittävä ero yliopistoihin nähden. Mm. Jyväskylän yliopistossa muutamia vuosia sitten tehty tutkimus on osoittanut, että amk-tutkinnon ja yliopistotutkinnon suorittaneet suuntautuvat hiukan erilaisiin tehtäviin. Suuntautumisen perusteena lienee juuri se, onko koulutus suunnittelupainotteista ja perustuuko se abstraktiin ajatteluun ja tieteelliseen tietoon vai perustuuko se sekä tietoon että ammatilliseen käytäntöön.

\section{Harjoitteluyrityksestä oppimisympäristöksi}

Käytännön ja teorian yhdistäminen asiantuntijuudeksi edellyttää oppimisympäristön laajentamista työpaikoille. Hyvä oppimisympäristö ei synny työpaikoille itsestään, vaan siihen tarvitaan kaikkien osapuolten sitoutumista, selkeitä tavoitteita, koulutusta ja yhteistä käsitystä oppimisesta ja oppimismenetelmistä. Voitettavana on monia uhkatekijöitä ja esteitä, ennen kuin työpaikan oppimisympäristö toimii oppimisen tu-

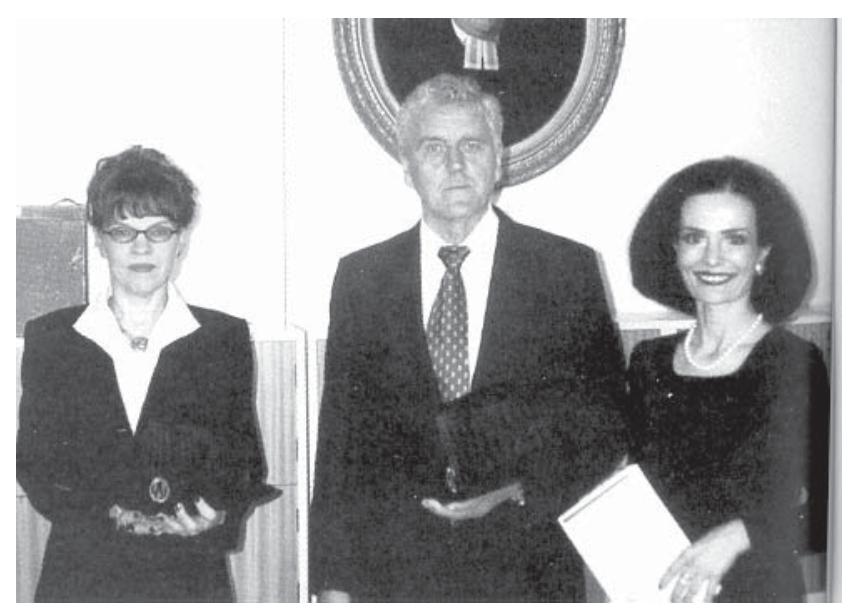

Väittelijä Marja-Liisa Vesterinen oikealla, keskellä viimeisen kerrankustoksenatoiminutprofessoriTapio Vahervaja vasemmallaensimmäisenkerranvastaväittäjänätoiminut professoriAnneli Eteläpelto.

kena ja edistäjänä. Harjoittelujaksolla ovat opettajan asemassa työpaikan ohjaajat ja muu henkilöstö. Työpaikan toimintatavat sekä sosiaalinen ja kulttuurinen vuorovaikutus toimivat työpaikan opetusmenetelminä. Harjoittelujaksolle menevä opiskelija itse tarvitsee oppimaan oppimisen taitoja, koska oppiminen työpaikan ihmisten keskustelusta, yhteistoiminnasta, tilanteista ja itse työstä on kovin erilaista kuin oppiminen koulussa kalvoilta ja kirjoista. Oppimaan oppimiseen ja opitun soveltamiseen on kiinnitettävä entistä enemmän huomiota.

\section{Kyky ja halu elinikäiseen oppimiseen}

Työssä oppiminen on tunnistettu yhä merkittävämmäksi oppimisen tavaksi ja lähteeksi sekä yritysten henkilöstökoulutuksessa että tutkintotavoitteisessa koulutuksessa. Työssä oppimien onkin elinikäisen oppimisen kulmakiviä. Kehityksen nopeus on johtanut siihen, että uusin tieto tulee usein käytännöstä, eikä kirjoista. Uuden tiedon on kuljettava työstä kouluun, koulusta työhön ja sitä on kehitettävä ja kokeiltava myös työelämän ja koulun yhteisissä kehittämis- ja tutkimusprojekteissa. Viime mainittuun tutkimukselliseen osaan luetaan myös opiskelijoiden opinnäytetyöt, jotka harjoittelun kehittämisprojektissa on pyritty tekemään harjoitteluyrityksestä saaduista aiheista. 


\section{Amk:n t\&t-toiminnalla työelämän käytännöt julki ja kehitettäväksi}

$\mathrm{A}$ mmattikorkeakoulujen tehtävänä on vaikuttaa tietoisesti ja aktiivisesti siihen, millaisia muutoksia työelämässä tulee tapahtumaan. Mietinnössä uudeksi amk-laiksi esitetään, että ammattikorkeakouluopetuksen tulee perustua ensisijaisesti työelämän ja sen kehittämisen vaatimuksiin. Opetuksen lisäksi kuuluu amk:n tehtäviin työelämää ja aluekehitystä tukeva tutkimustyö.

Yliopistojen tehtävänä on tehdä tieteellistä tutkimusta. Amk:n tehtävänä on tehdä tutkimusta, joka paitsi kehittää työelämän vallitsevia käytäntöjä ja käsityksiä, niin myös tutkimusta, jonka avulla voidaan pukea sanoiksi (=käsitteellistää, tuoda yleiseen tietouteen ja kuvata) työelämän käytännön teoriaa (practical theory). Ilman tutkimusta ko. tieto ja osaaminen jää hiljaiseksi tiedoksi tai vain tietyillä työpaikoilla olevaksi tiedoksi, vaikka olisi hyödyllistä saada käytännön hyvä osaaminen kaikkien käyttöön ja jatkojalostettavaksi. Amk-tutkimus yhdistää ammatillisen ja tieteellisen tiedon kahdensuuntaisesti: tuo käytännöstä lisää tietoa tieteellisen tiedon rinnalle ja tarkistaa, onko tieteellisellä tiedolla jotain annattavaa tähän käytäntöön sekä toisaalta perustelee käytäntöön soveltamista tieteellisellä tutkimustiedolla.

Tällainen käytännön teoria (toimintaa todellisuudessa ohjaava käyttöteoria) on kirjatiedon (teoreettisen tutkimustiedon, julkiteorian) rinnalla ensi arvoisen tärkeää ammattikorkeakoulun opetukselle, jotta ammatillista osaamista voi syntyä ja jotta voidaan kehittää koulutusta ja työelämää. Tutkimuksella ( Marsick \& Watkins 1990) todistettu fakta on se, että työelämässä olevat henkilöt oppivat työssäoloaikanaan uutta $80 \%$ :sesti työnsä kautta, siis nimenomaan työelämässä vallitsevan käytännön tiedon kautta työyhteisöjen sosiaalisessa vuorovaikutuksessa. Tämä kuvastaa hyvin sitä arvokkaan tiedon määrää, joka työelämässä piilee ja joka amk:n tutkimuksella voidaan julkituoda käytännön teoriaksi. Teoksessa Johdatusta ammattikorkeakoulupedagogiikkaan tätä asiaa kuvataan näin: Ammattikorkeakoulujen tiedonmuodostuksessa on nähty keskeiseksi käytännöstä käsin tapahtuva teorianmuo- dostus eli praktinen teoreettinen tietämys (Ekola 1992, 60). Ammattikorkeakoulujen tehtävänä on luoda tieteellisen teorian rinnalle käytännön teoriaa (Eteläpelto 1992, 26). Työelämän käytäntöjen tutkimisesta, mallintamisesta ja kehittämisestä, työyhteisöjen ihmisillä olevan hiljaisen tiedon julkituomisesta ja jalostamisesta sekä käytännön teorian luomisesta löytyy ammattikorkeakoulujen tutkimus- ja kehitystyön focus.

Jotta tällaisiin haasteisiin voidaan vastata, on ammattikorkeakoulun henkilöstön tunnettava hyvin työelämää, sen käytäntöjä ja tarpeita ja pystyttävä myös ohjaamaan kehitystä sekä opetuksen että tutkimus- ja kehitystyön avulla. Ammatillisen harjoittelun yhteydessä voidaan luontevasti toteuttaa opetuksen ja työelämän välistä yhteistyötä sekä osaamispääoman kasvattamista puolin ja toisin. Harjoittelun yhteydessä syntyvä yhteistyö ja kehittävä transfer sekä sosiaalinen, yhteistoiminnallinen oppiminen tarjoavat uusia osallistumisahdollisuuksia riviopettajillekin, jotka eivät muuten ole osallistuneet amk:n t\&k-työhön.

\section{Ammattikorkeakoulun opetus ja työelämän käytännöt paranevat}

Väitöstutkimukseni aikana havaitsin, että harjoittelun uudistamisen tuloksena opettajien työelämätietous, käytäntöjen tunteminen ja yhteistyö yritysten kanssa paranivat. Myös opiskelijat voidaan saada omaksumaan työelämää kehittävä aktiivinen ote ja muutoksen hallinnan taito huolehtimalla siitä, että sekä opettajilla että opiskelijoilla on henkilökohtaista yhteistyötä ja vuorovaikutusta työelämän kanssa. Vuorovaikutusta voidaan toteuttaa monella eri tavalla: työskentelemällä tai harjoittelemalla jossain yrityksessä, toimimalla opiskelijoiden harjoittelun ja opinnäytetyön ohjaajana tai työelämäprojekteissa, pyytämällä vierailevia luennoitsijoita yrityksistä koululle tai lähtemällä opettajan työelämäjaksolle "harjoittelemaan" käytäntöä ja havainnoimaan mahdollisia muutoksia tai muutostarpeita.

Ammattikorkeakouluja on kehitetty niiden kymmenvuotisen historian aikana asia kerrallaan. Tutkimukseeni sisältynyt harjoittelun kehittäminen on odottanut vuoroaan varsin pitkään. Ammattikorkeakoulujen koulutusohjelmiin sisäl- 
tyy 20 opintoviikon verran harjoittelua työelämässä. Harjoittelu ei ole tyydyttänyt opiskelijoita eikä opettajia sen enempää sisällöltään kuin organisointitavoiltaankaan. Harjoittelulle ei ole asetettu oppimistavoitteita, eikä sitä ole liitetty osaksi opetussuunnitelmaa. Harjoittelun opintoviikot ovatkin olleet melkoisessa hukkakäytössä siitäkin huolimatta, että ne ovat esimerkiksi 3.5vuotisessa tradenomikoulutuksessa $14 \%$ koko opinnoista. Ammatillinen harjoittelu on kuitenkin yksi luontevimpia ja aidoimpia tapoja saada opiskelijat oppimaan ammatillisia tehtäviä ja kehittämään osaamistaan aloittelijasta kohti pätevän ammattilaisen tasoa. Tällöin siirtyminen työelämään on tutkinnon suorittamisen jälkeen helppoa ja työnantajat saavat tarvitsemaansa valmista ammatillista osaamista.

\section{Näin tutkimus tehtiin}

$\mathrm{T}$ utkimukseni liittyi Etelä-Karjalan ammattikorkeakoulussa syksystä 2000 alkaneeseen ammatillisen harjoittelun kokeilu- ja kehittämisprojektiin (AMHA), jossa olen toiminut projektipäällikkönä. Väitöskirjassani olen raportoinut projektin kahta ensimmäistä kierrosta. Harjoitteluprojektissa on uudistettu kolmannen vuosikurssin opiskelijoiden harjoittelua. He ovat tuolloin jo opintojen syventävässä vaiheessa ja opiskelevat pääosin oman koulutusohjelmansa tai suuntautumisvaihtoehtonsa ammatillisia asioita. Tutkimuksessa oli mukana 36 opiskelijaa, 20 opettajaa ja 36 työpaikan pääohjaajaa. Tutkimuksen ulkopuolella olleita vertailuryhmiä oli sama määrä. Tutkimusaineisto koostui triangulaationa edellä mainittujen kolmen osapuolen alku- ja loppuhaastatteluista, opiskelijoiden lomakekyselystä, oppimispäiväkirjoista ja -tehtävistä, harjoittelujakson väli- ja purkuseminaarien sekä projektiryhmän palaverien tapahtumista, muistioista ja havainnoista.

Sekä tutkimukseni että sen rinnalla toteutettu harjoittelun kehittämisprojekti noudattivat toimintatutkimuksen strategiaa, jossa suunnittelu, toiminta, havainnointi ja reflektiivinen arviointi linkittyivät toisiinsa kahden harjoittelukierroksen ajan. Tutkimusta ohjanneen viitekehyksen osatekijöitä olivat käsitys asiantuntijuudesta ja ammatillisesta kompetenssista, työssä op- piminen ja oppimisympäristön laajentuminen työpaikoille, konstruktivistinen, kokemuksellinen ja reflektiivinen oppiminen, kehittävä transfer työn ja koulun kesken sekä yhteistoiminnallinen ja sosiaalinen oppiminen.

Tutkimuksessani selvitin, miten opiskelijoiden ammatillista harjoittelua, vanhemmalta nimeltään työharjoittelua, tulee kehittää ja miten harjoittelu tulee organisoida, jotta opiskelijoiden ammatillinen asiantuntijuus, todellinen osaaminen kehittyisi harjoittelun tuloksena. Asiantuntijuuteen katsotaan kuuluvan sekä teoriatietoa, käytännön tietotaitoa ja metakognitiivisia taitoja, joten opinnot eivät voi muodostua pelkästä muodollisesta koulussa tapahtuvasta oppimisesta ilman työssä syntyviä kokemuksia, mahdollisuuksia soveltaa koulussa opittua tai ilman työyhteisön sosiokulttuurisessa vuorovaikutuksessa syntyvää oppimista.

Tutkimuksessani olen myös selvittänyt, mitä asiantuntijuuden eri osa-alueisiin sisältyviä tietoja ja taitoja voidaan oppia harjoittelujaksolla ja minkälaisia työtehtäviä ja oppimista tukevia pedagogisia menetelmiä harjoittelujaksolla tulee olla, jotta harjoittelu tuottaa lisäarvoa opiskelijoiden osaamiseen. Lisäksi olen tutkinut, muuttaako ammatillinen harjoittelu uudistetussa muodossaan opettajien asennetta työssä oppimista kohtaan ja kehittääkö se heidän työelämäsuhteitaan. Tutkimuksessa selvitin myös, voidaanko harjoittelu integroida ja koordinoida osaksi muuta opetussuunnitelmaa ja mitä amk:n opettajat ja harjoitteluyritysten henkilöstö voivat oppia kehittävän transfervaikutuksen ansiosta, kun amk:n ja työelämän yhteistyö tiivistyy ja monipuolistuu harjoitteluprosessin seurauksena.

\section{Edellytykset työssä oppimiseen ensin kuntoon}

Koska tutkimukseni on osa ammattikorkeakoulun kokonaisvaltaista kehittämistyötä, olen myös selvittänyt, millä tavoin opetushenkilöstön, opiskelijoiden ja työpaikkaohjaajien oppimiskäsityksiä ja käytettäviä pedagogisia menetelmiä tulisi kehittää, jotta konstruktiivinen tiedon rakentelu ja yhteisöllinen oppiminen voisivat toteutua. Projektin ja tutkimuksen aikana pyrittiin opettajien, opiskelijoiden ja työpaikkaohjaajien 
koulutuksella vaikuttamaan siihen, että oppimiskäsitykset ja -menetelmät uusiutuisivat, eivät pelkästään harjoittelua varten, vaan kaikkea oppimista varten. Konstruktiivinen ja yhteisöllinen oppiminen, oman ajattelun ja reflektiivisyyden kehittyminen sekä erilaisten oppimisen pedagogisten välineiden, kuten oppimispäiväkirjojen ja -tehtävien käyttö oppimisen tukena oli osa sitä prosessia, jolla oppimaan oppimisen edellytyksiä parannettiin.

\section{TUTKIMUSTULOKSET}

\section{Osaaminen kasvaa kaikilla asiantuntijuuden osa- alueilla}

Tulokset osoittavat, että työpaikoilla tapahtuva oppiminen kasvattaa opiskelijoiden osaamista ja ammatillista asiantuntijuutta työelämän avaintaitojen, liike-elämän kokonaisosaamisen sekä ammatillisen erityisosaamisen alueilla. Opiskelijat oppivat työpaikka- ja alakohtaista työelämän käyttötietoa ja ammattitietoutta, työpaikan työprosessitietoutta sekä työstä toiseen siirtyviä työelämän avaintaitoja. Osaaminen kasvoi sekä laadullisesti että määrällisesti.

\section{Teoria ja käytäntö yhdistyvät}

Ammatillisessa harjoittelussa toteutuu ammattikorkeakoulun tavoite yhdistää teoria ja käytäntö. Opiskelijoiden ammatillinen asiantuntijuus kehittyy kaikilla asiantuntijuuden osa-alueilla. Opiskelijat oppivat ymmärtämään koulussa opittua teoriaa syvemmin $(23 \%$ merkittävistä oppimiskokemuksista) ja he oppivat käytännön tietoja ja taitoja (53\% oppimiskokemuksista). Li-

TAULUKKO 1. Välittömiä oppimistuloksia harjoittelujaksolta perustuen opiskelijoiden itsearviointiin ja haastatteluihin (* Taulukossa sv tarkoittaa suuntautumisvaihtoehtoa koulutuksessa)

\begin{tabular}{|c|c|c|c|c|c|c|c|c|c|c|c|c|c|c|}
\hline & \multicolumn{3}{|c|}{$\begin{array}{l}\text { Oppimiskokemuksen } \\
\text { täsmennys }\end{array}$} & \multicolumn{10}{|c|}{$\begin{array}{l}\text { Mikä saa aikaan oppimiskokemuksen? merkitse } \\
\text { enintään } 5 \text { tärkeintä numeroa ( } 1=\text { tärkein jne })\end{array}$} \\
\hline & & 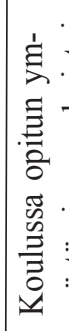 & 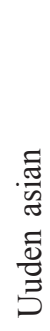 & 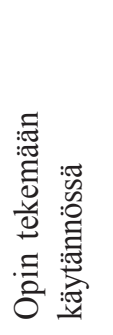 & 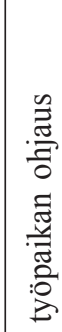 & 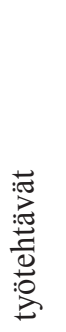 & 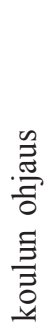 & 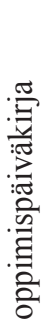 & 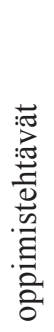 & 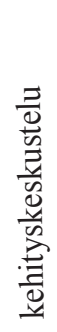 & 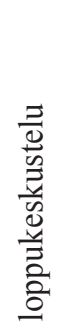 & 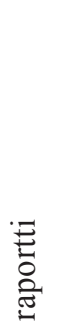 & 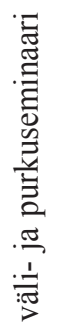 & 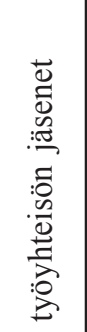 \\
\hline \multirow{2}{*}{ 学变 } & $\begin{array}{l}\text { Yleiset työelämä- } \\
\text { valmiudet }\end{array}$ & 39 & 43 & 115 & 59 & 126 & 23 & 11 & 13 & 17 & 10 & 4 & 1 & 87 \\
\hline & $\begin{array}{l}\text { Liike-elämän } \\
\text { arvot ja kulttuuri }\end{array}$ & 17 & 22 & 56 & 36 & 59 & 9 & 6 & 4 & 9 & 10 & - & 1 & 175 \\
\hline 宣交亩 & $\begin{array}{l}\text { Liike-elämän } \\
\text { kokonais- } \\
\text { osaaminen }\end{array}$ & 34 & 27 & 55 & 42 & 84 & 8 & 16 & 13 & 8 & 2 & 11 & 1 & $1 \quad 39$ \\
\hline \multirow[t]{3}{*}{ 党交至 } & \begin{tabular}{|l|} 
Omaan sv-koulu- \\
tusohjelmaan *) \\
liittyvä osaaminen
\end{tabular} & 37 & 39 & 58 & 46 & 79 & 19 & 8 & 16 & 13 & 5 & 9 & & 130 \\
\hline & $\begin{array}{l}\text { Yhteensä } \\
\text { \%-osuus }\end{array}$ & $\begin{array}{r}127 \\
23\end{array}$ & $\begin{array}{l}131 \\
24\end{array}$ & $\begin{array}{r}284 \\
53\end{array}$ & 183 & 348 & 59 & 41 & 46 & 47 & 27 & 24 & & 4231 \\
\hline & $\begin{array}{l}\text { Sija tärkeys- } \\
\text { järjestyksessä }\end{array}$ & & & & 3. & 1. & 4. & & & 5. & & & & 2 \\
\hline
\end{tabular}




\begin{tabular}{|c|c|c|c|}
\hline EDELLYTYKSET & \multicolumn{3}{|c|}{ HARJOITTELUNOPS HARJOITTELU- VAIKUTTAVUUS } \\
\hline \multicolumn{2}{|l|}{ Oppimistavoitteet } & $\begin{array}{l}\text { PROSESSI } \\
\text { Oniskeliiat }\end{array}$ & \\
\hline $\begin{array}{l}\text { - tutkinnon tavoittee } \\
\text { - integroitu opetus- } \\
\text { suunnitelma }\end{array}$ & $\begin{array}{l}\text { et -oppimistavoitteet } \\
\text { - opiskelijan hops } \\
\text { - liittyminen muuhun } \\
\text { opetussuunnitelmaan }\end{array}$ & $\begin{array}{l}\text { - työtehtävät } \\
\text { - muut oppimis- } \\
\text { kokemukset }\end{array}$ & $\begin{array}{l}\text { - oppimistulokset } \\
\text { - opinnäytetyön aihe } \\
\text { - valmistumisaika } \\
\text { - työkokemus }\end{array}$ \\
\hline Kriittiset oppimis- & & & - työllistyminen \\
\hline \multirow{4}{*}{$\begin{array}{l}\text { prosessit } \\
\text { - reflektiivinen } \\
\text { oppiminen } \\
\text { - konstruktiivinen } \\
\text { oppimiskäsitys }\end{array}$} & - oppimispäivä- & & \\
\hline & - oppir & \multicolumn{2}{|c|}{ kirja ja -tehtävät Ammattikorkeakoulu } \\
\hline & nenetelmät & - ohjaus & - osaaminen, imago \\
\hline & $\begin{array}{l}\text { - ohjauksen laatu } \\
\text { - välitapaamiset }\end{array}$ & - raportit & $\begin{array}{l}\text { - oppimiskäsitys ja } \\
\text { - menetelmät }\end{array}$ \\
\hline $\begin{array}{l}\text { - oma ajattelelu, } \\
\text { itseohjautuvuus }\end{array}$ & & $\begin{array}{l}\text { - kehitys- ja } \\
\text { loppukeskustelu }\end{array}$ & $\begin{array}{l}\text { - integroitu, uudistunut } \\
\text { ops ja oppimisympäristö }\end{array}$ \\
\hline $\begin{array}{l}\text { - yhteistoiminnal- } \\
\text { linen oppiminen } \\
\text { - oikeiden asioi- } \\
\text { den arviointi }\end{array}$ & $\begin{array}{l}\text { - } \text { arviointi } \\
\text { - } \text { itsearviointi }\end{array}$ & $\begin{array}{l}\text { - itsearviointi, } \\
\text { arviointi } \\
\text { - sosiaalinen vuoro } \\
\text { vaikutus, keskust } \\
\text { - purkuseminaari }\end{array}$ & $\begin{array}{l}\text { - täyttöaste, valmistumis- } \\
\text { ajat, valmistuneet } \\
\text { o- } \\
\text { telut }\end{array}$ \\
\hline Tehokas oppiminen & & & Työelämä ja yhteiskunta \\
\hline - ohjeistus & & & - oppiminen \\
\hline - koulutus & & & - osaava tuleva työvoima \\
\hline $\begin{array}{l}\text { - harjoitteluun sopi- } \\
\text { vien työtehtävien } \\
\text { määrittely }\end{array}$ & $\begin{array}{l}\text { - työtehtävien kriteerit } \\
\text { - yritysverkon kriteerit }\end{array}$ & - harjoittelujakso & $\begin{array}{l}\text { - kehittävä vaikutus, } \\
\text { aluekehitys }\end{array}$ \\
\hline 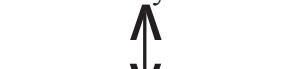 & 风 & 风 & , \\
\hline Jatkuva arviointi & iner & V & V \\
\hline
\end{tabular}

KUVIO: Ehdotus ammatillien harjoittelun malliksi ammattikorkeakouluille

säksi opiskelijat oppivat uusia työelämään liittyviä asioita (24\% oppimiskokemuksista), joita ei opeteta ja kenties ei voidakaan opettaa koulussa. Opiskelijoiden luottamus omaan osaamiseen ja kyky soveltaa sitä vahvistuivat. Myös ammatti-identiteetti kehittyi selvästi. Toisaalta opiskelijat huomasivat myös osaamisensa puutteet ja tutkinnon loppuun suorittamisen merkityksen.

\section{Työtoverit ja oikein suunnitellut työtehtävät oppi- misen avaintekijät}

Opiskelijoiden oppimiseen vaikuttivat eniten työyhteisön jäsenet ja työpaikan ohjaaja. Työskentelylle yhteisesti asetetut selkeät tavoitteet, oppimisen tukeminen ja ohjaus, mahdollisuus oman osaamisen soveltamiseen ja työpaikalla osoi- tettu luottamus ja turvallisuus vahvistavat osaamisen ja itseluottamuksen tunnetta sekä rohkeutta itsenäiseen työskentelyyn.

Harjoittelujakson työtehtävillä oli toiseksi suurin vaikutus opiskelijan oppimistuloksiin. Työtehtävien tulee sisältää ammattialaan liittyviä haasteellisia tehtäviä, mutta myös yleisiin työelämän käytäntöihin opettavia tehtäviä. Oppimista edistävät oppimistehtävät, oppimispäiväkirja, kehityskeskustelu ja loppukeskustelussa tehty itsearviointi sekä opiskelijoiden, ohjaajien ja opettajien ryhmätapaamiset sekä harjoittelun välija purkuseminaari.

Edellisten perusteella olen arvioinut, että ammatillinen harjoittelu nostaa amk-tutkinnon tasoa sekä laadullisesti että määrällisesti. Myös työ- 
paikkojen ohjaajat ja muu henkilöstö samoin kuin ammattikorkeakoulun opettajat voivat oppia uusia asioita toisiltaan tai reflektoimalla omia käsityksiään ja käytäntöjään ja kehittää uudenlaista yhteistyötä opetuksessa, projekteissa ja tutkimuksessa harjoittelun seurauksena.

\section{Harjoittelujaksolle selkeät tavoit- teet ja opetussuunnitelma}

Harjoittelu tulee integroida osaksi opetussuunnitelmaa, jossa harjoittelujaksolla oppimiselle määritellään yleisiä ja koulutusohjelmakohtaisia oppimistavoitteita (esim. kompetenssipohjaisesti) ja harjoittelu integroidaan muuhun opetussuunnitelmaan niin, että harjoittelun opintoviikot tulevat todella oppimisen käyttöön. Opetussuunnitelmassa määritellään harjoitteluun sopivat oppimismenetelmät, harjoittelun ohjauksen laatu, arviointi, harjoitteluun soveltuvien työtehtävien luonne, sopivien harjoitteluyritysten ominaisuudet ja harjoittelun integroituminen muuhun opetussuunnitelmaan. Harjoittelun opetussuunnitelmassa kuvataan myös konkreettisesti se, mitä harjoitteluprosessissa käytännössä tapahtuu.

Jotta konstruktivistinen ja sosiaalinen oppiminen voivat toteutua, tulee opiskelijoiden, opettajien ja työpaikan henkilöstön omaksua monia uusia pedagogisia menetelmiä ja harjoitella reflektiivisyyttä, kriittistä ajattelua, tiedon rakentelua, kyselemistä ja yhteisöllistä oppimista opintojen alusta alkaen. Tutkimus synnytti kymmenen jatkotutkimusaihetta. Ne jakautuvat amk:n oman toiminnan kehittämiseen ja toisaalta työpaikkojen oppimisympäristön ja osaamisen kehittäminen.

\section{Ammatillisen harjoittelun malli}

Olen tehnyt tutkimukseni tuloksena ehdotuksen harjoittelun malliksi ammattikorkeakouluille (kuvio1). Mallissa esitän käsitykseni siitä, mitä harjoittelujaksoon tulee sisältyä, mitä pedagogisia välineitä kannattaa hyödyntää ja miten oppiminen tunnistetaan, jotta opiskelijan osaaminen, itseluottamus, motivaatio ja ammatti-identiteetti kehittyvät.
Mallissa korostan, että itse harjoitteluprosessin lisäksi on huolehdittava siitä, että tuloksellisen harjoittelun edellytykset ovat kunnossa eli hyvä yritysverkko harjoittelupaikkoineen, koulutetut ohjaajat, sitoutuneet työyhteisöt, ammatillisesti kasvattavat työtehtävät, kyky oppia ja ohjata sekä rakentava oppimiskulttuuri. Mallia on sovellettu Etelä-Karjalan ammattikorkeakoulussa liiketalouden, matkailu, kotitalouspalvelujen ja tekniikan kolmen koulutusohjelman opiskelijoiden harjoittelussa. Oppimistulokset ovat kaikissa tapauksissa olleet hyvin samanlaisia ja hyviä.

Mallia voidaan soveltaa myös aikuiskoulutukseen ja työyhteisöjen henkilöstökoulutukseen. Tutkimukseni jälkeinen jatkotutkimus selvittää parhaillaan, mitä vaikutuksia harjoitteluprosessilla on harjoitteluyritysten työpaikkaohjaajien ja muun henkilöstön osaamiseen, toimintatapoihin ja oppimiskulttuuriin. Tässä vaiheessa on jo selvinnyt, että osa harjoitteluyrityksistä on huolehtinut osaamispääomastaan ja liiketoimintansa kehittämisestä esimerkillisen hienosti, kun taas luvattoman monesta työyhteisöstä heijastuu suuri haaste myös amk:n t-\&k-toiminnalle: työyhteisöissä ei edes tiedetä, mitä kaikkea ei tiedetä! Jatkotutkimuksella ja -projektilla lähdetäänkin selvittämään, miten amk-opettajien ja opiskelijoiden kehitys- ja työpanoksella voidaan saada pk-yritykset oppimaan ja omaksumaan uusia liiketoimintamalleja, erityisesti sähköisen liiketoiminnan käytäntöjä.

\section{Lähteet}

EKOLA, J. (1992). Johdanto. Teoksessa J. Ekola (toim.) Johdatusta ammattikorkeakoulupedagogiikkaan. Porvoo: WSOY, 9-15.

ETELÄPELTO, A., (1992). Tulevaisuuden asiantuntijuuden kehittämiseen. Teoksessa J. Ekola (toim.) Johdatusta ammattikorkeakoulupedagogiikkaan. Porvoo: WSOY, 19-42.

MARSICK V.J. \& Watkins K.E. (1990). Informal and incidental learning in the workplace. London: Routledge.

Marja-Liisa vesterinen väitteli Jyväskylänyliopistossa tutkimuksellaan "Ammatillinen harjoitteluosanaasiantuntijuuden kehittymistä ammattikorkeakoulussa" 4. kesäkuuta 2002. Vastaväittäjänätoimi professoriAnneli Eteläpelto Helsingin yliopistosta. 